\title{
Cold Atmospheric Pressure Plasma in Wound Healing and Cancer Treatment
}

\author{
Lars Boeckmann ${ }^{1, *}{ }^{-}$, Mirijam Schäfer ${ }^{1}\left(\mathbb{D}\right.$, Thoralf Bernhardt ${ }^{1}\left(\mathbb{D}\right.$, Marie Luise Semmler ${ }^{1}$, \\ Ole Jung ${ }^{1}$, Gregor Ojak ${ }^{1}$, Tobias Fischer ${ }^{1}$, Kirsten Peters ${ }^{2}{ }^{(D}$, Barbara Nebe ${ }^{2}{ }^{(D}$,

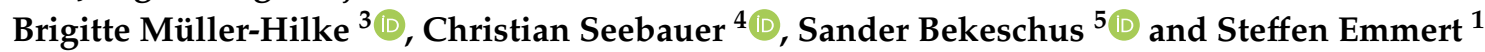 \\ 1 Clinic and Polyclinic for Dermatology and Venereology, University Medical Center Rostock, \\ 18057 Rostock, Germany; mirijam.schaefer@med.uni-rostock.de (M.S.); \\ thoralf.bernhardt@med.uni-rostock.de (T.B.); luise.semmler@med.uni-rostock.de (M.L.S.); \\ ole.jung@med.uni-rostock.de (O.J.); gregor.ojak@med.uni-rostock.de (G.O.); \\ tobias.fischer@med.uni-rostock.de (T.F.); steffen.emmert@med.uni-rostock.de (S.E.) \\ 2 Department of Cell Biology, University Medical Center Rostock, 18057 Rostock, Germany; \\ kirsten.peters@med.uni-rostock.de (K.P.); barbara.nebe@med.uni-rostock.de (B.N.) \\ 3 Institute for Immunology, University Medical Center Rostock, 18057 Rostock, Germany; \\ brigitte.mueller-hilke@med.uni-rostock.de \\ 4 Oral \& Maxillofacial Surgery/Plastic Surgery, University Medicine Greifswald, 17489 Greifswald, Germany; \\ seebauerc@uni-greifswald.de \\ 5 ZIK Plasmatis, Leibniz Institute for Plasma Science and Technology (INP), 17489 Greifswald, Germany; \\ sander.bekeschus@inp-greifswald.de \\ * Correspondence: lars.boeckmann@med.uni-rostock.de; Tel.: +49-381-494-9760
}

Received: 24 August 2020; Accepted: 29 September 2020; Published: 1 October 2020

\begin{abstract}
Plasma medicine is gaining increasing attention and is moving from basic research into clinical practice. While areas of application are diverse, much research has been conducted assessing the use of cold atmospheric pressure plasma (CAP) in wound healing and cancer treatment-two applications with entirely different goals. In wound healing, a tissue-stimulating effect is intended, whereas cancer therapy aims at killing malignant cells. In this review, we provide an overview of the latest clinical and some preclinical research on the efficacy of CAP in wound healing and cancer therapy. Furthermore, we discuss the current understanding of molecular signaling mechanisms triggered by CAP that grant CAP its antiseptic and tissue regenerating or anti-proliferative and cell death-inducing properties. For the efficacy of CAP in wound healing, already substantial evidence from clinical studies is available, while evidence for therapeutic effects of CAP in oncology is mainly from in vitro and in vivo animal studies. Efforts to elucidate the mode of action of CAP suggest that different components, such as ultraviolet (UV) radiation, electromagnetic fields, and reactive species, may act synergistically, with reactive species being regarded as the major effector by modulating complex and concentration-dependent redox signaling pathways.
\end{abstract}

Keywords: cancer therapy; cold physical plasma; dermatology; plasma medicine; reactive oxygen and nitrogen species

\section{Introduction}

In recent years, the field of plasma medicine is gaining more and more attention. Cold atmospheric pressure plasma (CAP) is composed of a complex mixture of biologically active components that may act synergistically on the treated materials and tissues and may have a variety of different biologic effects. The partially ionized gas mixture includes chemical and physical components, such as different reactive oxygen and nitrogen species (RONS), charged atoms and molecules, electrons, ultraviolet (UV) 
radiation, visible light, and electromagnetic fields [1]. The application spectrum of CAP ranges from decontamination, coagulation, surface treatment of implants, dentistry, as well as cosmetic and plastic surgery to skin diseases and cancer treatment [2,3]. A substantial number of studies have been conducted concerning different CAP applications in dermatology. While a significant portion of the early studies focused on disinfection and wound healing, CAP has also been investigated regarding its effects on reducing itch and pain, atopic eczema, scars, epidermal barrier defects (ichthyosis) [4]. An increasing number of studies focus on the use of CAP for cancer treatment [5]. While safety and the beneficial use of CAP as part of a multi-modular wound treatment has been demonstrated in several structured case reports and randomized case-control studies, the use of CAP for cancer treatment is an active field of research that warrants further investigations for its translation into clinic practice. For these two quite different applications of CAP, different properties of CAP are required. For wound healing, antiseptic and tissue regenerating properties are needed, whereas for cancer treatment, anti-proliferative and cell death-inducing properties are desired. These properties can be controlled by the parameters of treatment time and intensity. Higher intensities and treatment times are needed for cancer treatment, but pose a higher risk for adverse side effects.

This review article provides an overview of the latest literature regarding the clinical use of CAP for wound healing and cancer treatment. It discusses possible underlying mechanisms triggered by CAP that grant CAP antiseptic and tissue regenerating or anti-proliferative and cell death-inducing properties.

\section{CAP Treatment to Promote Healing of Acute and Chronic Wounds}

A couple of smaller studies and case reports assessed the safety and efficacy of cold atmospheric pressure plasma (CAP) to treat acute and chronic wounds (Table 1). The first studies primarily aimed at showing the safety of different CAP devices and a reduction of bacterial load in chronic wounds [6-9]. For example, two prospective randomized and controlled studies assessing the use of a plasma jet (MicroPlaSter, the predecessor of SteriPlas, Adtec Healthcare; Adtec Plasma Technology Co. Ltd., Hiroshima, Japan/London, U.K.), including 36 and 24 patients with chronic wounds, respectively, showed a significant reduction of the bacterial load [6,7]. A case-control study comparing the efficacy of another plasma jet device (kINPen MED, neoplas tools GmbH, Greifswald, Germany) with octenidine dihydrochloride (octenidine) treatment revealed a similar anti-bacterial effect in the CAP group compared to the octenidine group [9]. A similar study of the same 34 patients showed advantages regarding the antimicrobial efficacy of sequential treatment with CAP and Octenidine versus mono-treatment of just one of the two antiseptic treatments [8].

While the primary endpoint of these studies was safety and bacterial load, a retrospective follow-up study of the two studies by Isbary and colleagues [6,7] revealed that CAP might accelerate the healing of chronic wounds [10]. A first monocentric two-armed, open, prospective, randomized, and controlled pilot-study regarding CAP treatment of chronic leg venous ulcers used a dielectric barrier discharge plasma source (PlasmaDerm VU-2010, Cinogy GmbH, Duderstadt, Germany) and included 14 patients [11]. Half of the patients received standard wound care, and the other half received CAP treatment in addition to standard wound care. In both groups, a reduction of wound size by about $50 \%$ was observed, whereas, after three weeks, a faster and stronger reduction of wound size was observed in the CAP treated group. One patient in the CAP treated group experienced complete healing.

In the so far discussed studies, wound healing was examined either as a secondary endpoint or retrospectively. A comprehensive prospective, randomized, controlled trial comprising 50 patients, however, specifically assessed wound size reduction of pressure-induced ulcers after CAP treatment (BIOPlasma jet, PhotoBioCare, Nonthaburi, Thailand) and revealed a significantly accelerated wound size reduction in the CAP treated group [12].

Besides investigating the effect of CAP on chronic wounds, studies have also been conducted to assess the effects of CAP on acute wounds. In a series of case-reports, four sterile laser skin lesions were 
induced in five volunteers [13]. These acute wounds were treated for either $10 \mathrm{~s}$, three times $10 \mathrm{~s}, 30 \mathrm{~s}$ with CAP (kINPen MED, neoplas tools GmbH, Greifswald, Germany), or left untreated. Treatment for three times $10 \mathrm{~s}$ and one time $30 \mathrm{~s}$ showed the best outcome for early wound healing, as well as 6 and 12 months after treatment [14]. A significantly improved healing of vacuum-generated acute wounds was observed after CAP treatment (kINPen, neoplas tools GmbH, Greifswald, Germany) in comparison with either no treatment, octenidine treatment, or sequential CAP and octenidine treatment [15]. Significantly improved wound healing was also observed after CAP treatment (MicroPlaSter $\beta$, Adtec Plasma Technology Co. Ltd., Hiroshima, Japan/London, U.K.) compared to placebo in a study assessing the effect of CAP on skin graft donor sites [16]. Half of the skin graft donor wounds were randomly treated CAP, and the other half received placebo treatment. The healing of the wounds was assessed in a blinded fashion by independent experts.

Despite these multiple indications for a positive influence of CAP on wound healing, a meta-analysis published 2019 came to the conclusion that CAP treatment based on the included studies has no significant effect on wound healing over standard care [17]. This meta-analysis, however, included only four of the above-discussed studies [9-11,16]. In these studies, three different CAP sources have been used, and studies investigating the effects of CAP on chronic wounds, as well as on acute wounds, have been included. Particularly, the study by Chuangsuwanich and colleagues, which assessed wound size as the primary endpoint and showed a significant effect of the CAP treatment, was not included in the meta-analysis. Further evidence for a positive effect of CAP on wound healing comes from a recently published prospective, randomized, placebo-controlled, blinded, multi-centered study, including 65 chronic wounds of 45 patients with diabetic leg ulcers [18]. While all patients received standard wound care, 33 wounds were treated additionally with eight applications of CAP (kINPen MED, neoplas tools GmbH, Greifswald, Germany), and the other 32 wounds were treated with placebo (argon gas flowing through the kINPen MED device without ignition of plasma). This randomized clinical trial revealed a significantly stronger reduction in wound size and accelerated time to relevant wound area reduction. Interestingly, no significant difference in the reduction of infection and the microbial load was observed between CAP and placebo groups. This suggests that improved wound surface reduction and time to wound closure was independent of background infection [18]. Similar results were presented from another recent randomized clinical trial assessing the use of CAP (plasma jet, self-constructed) to treat diabetic foot ulcers [19]. Patients were randomly and double-blinded assigned to one group receiving standard care alone, and another group receiving standard care and CAP (22 patients per group). Primary endpoints were wound size and bacterial load. It was found that CAP significantly accelerates wound healing of diabetic foot ulcers. Immediate antiseptic effects have been observed as well, but these do not seem to last long [19].

Although the here discussed studies and several single case-reports show beneficial effects of $\mathrm{CAP}$ on wound healing in general, not every patient benefits from the treatment. Hence, more research is needed to optimize CAP treatment regarding the type of plasma source, plasma treatment time, and plasma treatment intervals. Furthermore, it is conceivable that parameters, such as age, smoking, alcohol consumption, or body-mass-index, play a significant role regarding the efficacy of the treatment. Further comprehensive studies will bring about further insights on parameters that may have a positive or negative influence on CAP treatment success and thus may help to stratify patients before treatment.

Table 1. Clinical trials and case reports of CAP application for treatment of chronic and acute wounds, as well as (pre-)cancerous tissues.

\begin{tabular}{llll}
\hline \multicolumn{1}{c}{ Plasma Source } & Treatment of & Number of Participants & Reference (Year) \\
\hline MicroPlaSter $\alpha$ & Chronic wounds & 36 & {$[6](2010)$} \\
CPC 1500 System (jet) & Pleural mesothelioma & 8 & {$[20](2010)$} \\
MicroPlaSter $\alpha / \beta$ & Chronic wounds & 24 & {$[7](2012)$} \\
kINPen & Acute wounds & 5 & {$[13](2012)$} \\
MicroPlaSter $\alpha / \beta$ & Chronic wounds & 70 & {$[10](2013)$} \\
MicroPlaSter $\beta$ & Acute wounds & 34 & {$[16](2013)$} \\
\hline
\end{tabular}


Table 1. Cont.

\begin{tabular}{llll}
\hline \multicolumn{1}{c}{ Plasma Source } & Treatment of & Number of Participants & Reference (Year) \\
\hline kINPen & Acute wounds & 6 & {$[15](2014)$} \\
kINPen & Chronic wounds & 34 & {$[8](2015)$} \\
PlasmaDerm & Chronic wounds & 14 & {$[11](2015)$} \\
kINPen & Chronic wounds & 16 & {$[9](2015)$} \\
kINPen & Advanced squamous cell carcinoma of & 12 & [21] (2015) \\
BIOPlasma jet & the head and neck & 50 & [12] (2016) \\
kINPen & Chronic wounds & Group I: 12 & [22] (2016) \\
Custom-made device with hand-held & Advanced squamous cell carcinoma of & Group II: 9 & [23] (2017) \\
electrode (FPG10-01NM10) & Actinic keratosis & 5 & [24] (2018) \\
kINPen & Locally advanced head and neck & 6 & [25] (2018) \\
Adtec Steri-Plas & cancers & 7 & [18] (2020) \\
kINPen & Actinic keratosis & 45 & 44 \\
plasma jet & Chronic wounds & Chronic wounds & \\
\hline
\end{tabular}

\section{CAP Application for Cancer Treatment}

Besides the tissue regenerating effects, CAP may also have detrimental effects on cells and tissues when prolonged treatment is performed, or higher intensities are applied [26]. This ability of CAP to inhibit cell proliferation and induce cell death prompted researchers to consider CAP as an innovative tool for cancer treatment. The growing interest in the potential use of CAP in oncology is represented by the increasing cumulative number of respective publications [27]. The vast majority of these studies were performed in vitro using cell cultures. For instance, an early study noted reduced viability and induced apoptosis in tumor cells after treatment with a plasma needle [28]. Adding to the large number of in vitro studies, a growing number of in vivo animal studies is supporting the potential use of CAP in cancer treatment. For instance, a study using a mouse model with induced tumors showed that in $66 \%$ of cases, the tumor completely regressed after CAP treatment, while untreated tumors in the control group kept growing continuously [29]. Another study reported a selectivity to ablate cancer cells using CAP, while the corresponding non-malignant cells remained unaffected [30]. Moreover, Bekeschus and colleagues have demonstrated that the plasma ROS chemistry can be optimized to maximize antitumor efficacy in vivo [31]. Whereas most studies assessed the use of CAP as a mono-therapy, some studies also demonstrate a beneficial effect of CAP as a combinatorial therapy, for example, in conjunction with the cytostatic drug gemcitabine [32]. In this study, mice were treated either with gemcitabine alone, CAP alone, or a combination of both and compared to an untreated control group. Analysis of the tumor weight 36 days after tumor induction and 12 days after the last treatment revealed a significant advantage of the combination therapy over each mono-therapy.

While results from in vitro and in vivo animal studies are very encouraging, indicating a considerable potential of CAP in oncology, clinical studies are still very sparse. A review containing an overview of current literature on clinical studies assessing the use of CAP in oncology has been published recently [33]. This paragraph provides also provides a short overview of those few clinical studies. In a study that did not directly aim at using CAP for cancer treatment, CAP was used as part of multimodal therapy of mesothelioma with the goal of avoiding accidental translocation of malignant cells to the abdomen [20]. Within a median observation time of about one year, no relapse of the disease has been observed, and no vital tumor cells were detected in tissue specimens. A pilot study assessing the use of CAP to reduce the bacterial load on locally advanced head and neck cancers to reduce typical fetid odor accidentally also revealed partial tumor remission in some of the patients [21]. Subsequent studies by the group revealed comparable results and showed an increasing number of apoptotic cells in CAP treated tumor tissues compared to non-treated tissues [22,24]. Total and partial remissions of actinic keratosis (precursor lesions of squamous cell carcinomas) after CAP treatment have been reported by two independent groups using different plasma devices [23,25]. Details on patient numbers and treatment modalities of the here described studies are summarized in Tables 1 and 2, respectively. 
Table 2. Frequently reported treatment parameters in clinical pilot studies and case reports of CAP application for treatment of chronic and acute wounds, as well as (pre-) cancerous tissues.

\begin{tabular}{|c|c|c|c|c|c|c|c|}
\hline Reference & Device & Type & Feed Gas & Treatment Time & Repetition & Distance & $\operatorname{slm}$ \\
\hline [6] & MicroPlaSter $\alpha$ & Torch & Argon & $5 \mathrm{~min}$ & daily (on average 7.86 treatments) & $20 \mathrm{~mm}$ & 2.2 \\
\hline [20] & CPC 1500 System (jet) & Jet & Helium & $15-46 \mathrm{~min}$ & once & & \\
\hline [7] & MicroPlaSter $\alpha / \beta$ & Torch & Argon & $2 \min$ & $\begin{array}{c}\text { daily (on average } 11.75 \\
\text { treatments) }\end{array}$ & & 2.2 \\
\hline [13] & kINPen MED & Jet & Argon & $10 \mathrm{~s}, 30 \mathrm{~s}$, or $3 \times 10 \mathrm{~s}$ & once & $10 \mathrm{~mm}$ & \\
\hline [10] & MicroPlaSter $\alpha / \beta$ & Torch & Argon & $3-7 \mathrm{~min}$ & daily (on average 7.90 treatments) & $20 \mathrm{~mm}$ & 2.2 \\
\hline [16] & MicroPlaSter $\beta$ & Torch & Argon & $2 \mathrm{~min}$ & daily except for weekend & $20 \mathrm{~mm}$ & 2.2 \\
\hline [15] & kINPen MED & Jet & Argon & $1 \mathrm{~min}(8 \mathrm{~mm} / \mathrm{s})$ & once & $10 \mathrm{~mm}$ & 5.0 \\
\hline [8] & kINPen 09 & Jet & Argon & $1 \mathrm{~min} / \mathrm{cm}$ & once & $7-8 \mathrm{~mm}$ & 5.0 \\
\hline [11] & PlasmaDerm & DBD & n/a (air) & $45 \mathrm{~s} / \mathrm{cm}^{2}$ & $3 \times$ week for 8 weeks & & $\mathrm{n} / \mathrm{a}$ \\
\hline [9] & kINPen MED & Jet & Argon & $1 \mathrm{~min} / \mathrm{cm}$ & $3 \times$ week for 2 weeks & $7-8 \mathrm{~mm}$ & 5.0 \\
\hline [21] & kINPen MED & Jet & Argon & $1 \mathrm{~min} / \mathrm{cm}^{2}$ & $3 \times$ week for 1 week & $8 \mathrm{~mm}$ & between $3-6$ \\
\hline [12] & BIOPlasma jet & Jet & Argon & $1 \mathrm{~min} / \mathrm{cm}^{2}$ & $1 \times$ week for 8 weeks & $1-3 \mathrm{~mm}$ & \\
\hline [22] & kINPen MED & Jet & Argon & $\begin{array}{l}\text { Group I: } 1 \text { min spot } \\
\text { exposure Group II: } \\
3 \text { min spot exposure }\end{array}$ & $\begin{array}{l}\text { Group I: } 3 \times \text { week for } 1 \text { weeks } \\
\text { Group II: once }\end{array}$ & $8 \mathrm{~mm}$ & \\
\hline [23] & $\begin{array}{l}\text { Custom-made device with } \\
\text { hand-held electrode } \\
\text { (FPG10-01NM10) }\end{array}$ & FE-DBD & n/a (air) & $1-2 \mathrm{~min}$ & once & $2.7 \mathrm{~mm}$ & $\mathrm{n} / \mathrm{a}$ \\
\hline [24] & kINPen MED & Jet & Argon & $1 \mathrm{~min} / \mathrm{cm}^{2}$ & $\begin{array}{c}3 \times \text { week for } 1 \text { week followed by } \\
\text { an intermittence of } 1 \text { week } \\
\text { without CAP }\end{array}$ & $8 \mathrm{~mm}$ & 5.0 \\
\hline [25] & Adtec Steri-Plas & Jet & & $2 \min$ & $2 \times$ week ( 7 treatments) & & \\
\hline [18] & kINPen MED & Jet & Argon & $30 \mathrm{~s} / \mathrm{cm}^{2}$ & $\begin{array}{c}5 \times \text { daily, then } 3 \times \text { every } \\
\text { second day }\end{array}$ & & \\
\hline [19] & plasma jet & Jet & Helium & $5 \mathrm{~min}$ & $3 \times$ week for 3 weeks & $10 \mathrm{~mm}$ & \\
\hline
\end{tabular}


In comparison to CAP use for wound healing, the clinical studies for CAP in oncology are still very sparse. Nonetheless, in vitro and in vivo studies, as well as the first clinical trials, are encouraging and warrant further efforts to prove the safety and efficacy of CAP as an innovative cancer therapy.

Since there are many different devices and parameters that may influence treatment efficacy for wound healing, as well as for cancer therapy, a direct comparison of these studies is difficult. Nonetheless, comparing the different parameters may help to decipher which settings may be most promising. An overview of the most frequently reported parameters is provided in Table 2.

\section{Properties of CAP Stimulate Tissue Regeneration but May also Induce Cell Death}

At first glance, it seems contradictory to use CAP on the one hand for wound healing to stimulate tissue regeneration, and on the other hand, for cancer therapy to inhibit cell proliferation and induce cell death. How can one application exhibit such opposite properties? As Paracelsus already stated in his Third Defense in 1538, "Sola dosis facit venenum"—only the dose makes the poison. This also holds true for CAP-low doses can be beneficial, while high doses can be destructive. Hence, when using CAP for wound treatment, "overdosing" should be avoided to prevent adverse effects. Likewise, "under-dosing" may not have the desired lethal effect on cancer cells when applying CAP for cancer therapy. Due to the vast range of different plasma devices and operating parameters being used in plasma medicine, the term "dose" is not well defined and somewhat controversial. Therefore, identifying the optimal treatment modalities for the different applications of CAP is one of the main challenges that need to be solved in future clinical trials.

To find the optimal treatment modalities for each application and clinical setting, it helps to understand the molecular mechanisms of action of CAP. Although progress has been made for understanding the underlying mechanisms of CAP in wound healing and cancer treatment, much still needs to be explored. In this section, the current understanding of the molecular mechanisms will be discussed briefly. As this is a very complex field and many aspects need to be considered, this overview is not intended to be comprehensive and may not be exhaustive and complete. Instead, it is meant to provide a basic understanding of how CAP may have stimulating or inhibiting properties (Figure 1).

The biological efficacy of CAP is mostly attributed to chemical components (e.g., reactive oxygen and nitrogen species (RONS)), physical components (e.g., electromagnetic fields and UV radiation) probably play a minor role. The effect of UV radiation most likely is negligible because UV exposure during CAP application for wound healing is far below natural UV exposure by the sun and below the general limits that have been determined for health and safety measures at work [7,34-36]. However, a limited degree of UV exposure may have synergistic effects in combination with other components of CAP.

Independent of CAP-derived electric fields, studies in bio-electrics have shown positive effects of pulsed electric fields on wound healing $[37,38]$. A meta-analyses assessing the effect of electrostimulation on wound healing concluded from 15 studiesa significantly accelerated wound reduction and increased number of healed wounds compared to respective controls [39]. The application of electromagnetic fields may influence several aspects of tissue biology and hence affect tissue regeneration. It can modulate the movement of immune cells, such as macrophages and granulocytes, as well as the migration of skin cells, such as keratinocytes. Furthermore, electrostimulation is of relevance to the proliferation of fibroblasts and the stimulation of angiogenesis. Anti-bacterial effects have also been reported [40-43]. Moreover, the combination of pulsed electric fields and CAP for palliative therapy in cancer patients has been discussed recently [44]. Considering this, it is conceivable that electromagnetic fields as part of CAP applications may contribute to accelerated wound healing. 


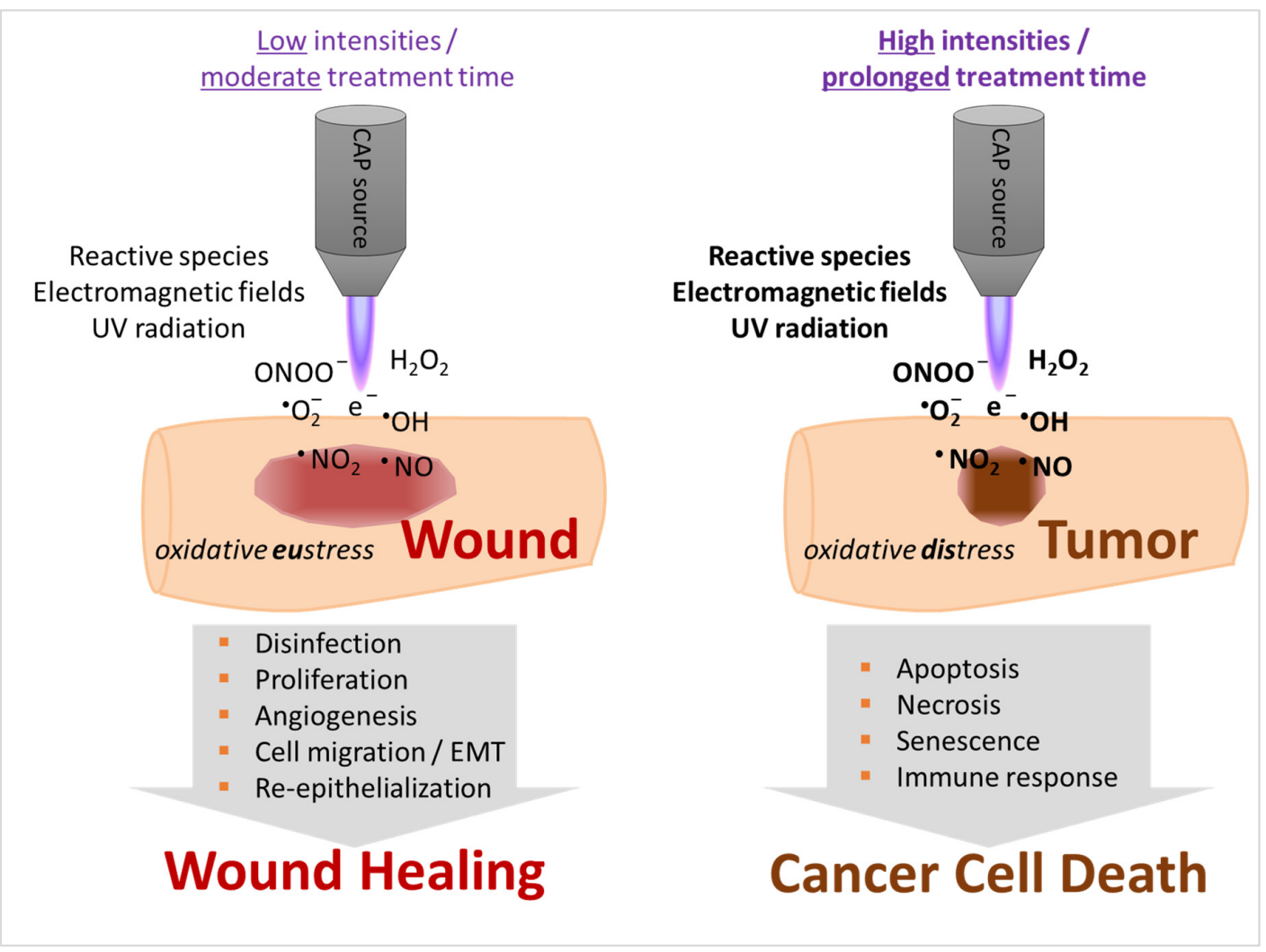

Figure 1. Cold atmospheric pressure plasma (CAP) in wound and cancer treatment. Wound healing, disinfection, and tissue regeneration are triggered by short or moderate CAP treatment (left panel). It is hypothesized that ultraviolet (UV) radiation, electromagnetic fields, and/or reactive oxygen and nitrogen species acting either alone or in concert contribute to the effects observed. Prolonged treatment for cancer therapy enhances oxidative stress from eustress to distress and hence will induce cancer cell death (right panel). EMT = epithelial-mesenchymal transition.

However, according to the current understanding, RONS are considered the most important components of CAP to mediate its biological effects. Therefore, the field of plasma medicine is also considered a field of applied redox biology [45]. RONS, such as hydroxyl radicals $(\mathrm{OH} \bullet)$, hydrogen peroxides $\left(\mathrm{H}_{2} \mathrm{O}_{2}\right)$, hyper oxides $\left(\mathrm{O}_{2}{ }^{-} \bullet\right)$, nitric oxides $(\mathrm{NO} \bullet)$, nitrogen dioxides $\left(\mathrm{NO}_{2} \bullet\right)$, and peroxynitrites $\left(\mathrm{ONOO}^{-}\right)$, generated by $\mathrm{CAP}$ are identical with reactive species generally produced during regular metabolism. They are known to mediate critical physiological and pathological processes, such as immune response, cell adhesion, and migration, apoptosis, skeletal muscle function, and wound healing [46]. Many of the ROS-mediated responses protect cells against oxidative stress and reestablish redox homeostasis [47]. RONS and the antioxidant system are regarded as secondary messengers to control various signaling pathways [48].

Wound healing often is described as a series of three overlapping consecutive phases [49]. The initial inflammation phase is characterized by increased exudation of blood plasma, and recruitment of macrophages and granulocytes, which degrade necrotic tissue and establish an antimicrobial environment. In the subsequent proliferation phase, granulation tissue is built, and new vascular structures are assembled (neovascularization). The final remodeling phase is characterized by the maturation of collagen fibers, immigration of epithelial cells from the edge of the wound, and finally, wound closure [50]. RONS are known to be essential for the initial stage of hemostasis by mediating tissue factor (TF-mRNA), platelet recruitment, and platelet activation [51]. It has been pointed out that RONS have a widespread and pervasive effect on promoting, but also resolving inflammation [52]. In doing so, not only the presence or absence of RONS, but also the concentration seems to play an essential role. While lower concentrations of nitric oxide, for example, tend to favor growth and 
inhibit apoptosis, higher concentrations promote cell-cycle arrest, senescence, or apoptosis [53]. Indeed, nitric oxide, which is involved in wound healing and is released primarily in the inflammatory phase, is one of the essential RONS [51,54,55]. Besides inflammation, its functional activity has been linked to angiogenesis, cell proliferation, matrix deposition, and remodeling [56]. During the inflammation phase of wound healing, nitric oxide is generated by neutrophils and macrophages through an enzymatic reaction catalyzed by the inducible nitric oxide synthase (NOS2) [48]. Hydrogen peroxide is also known as an active secondary messenger for a platelet-derived growth factor (PDGF), vascular endothelial growth factor (VEGF), and tissue growth factor (TGF) [51,57].

These examples show that temporarily elevated levels of RONS can be tolerated and have crucial physiological signaling roles. However, chronic oxidative stress, due to increased levels of RONS over more extended periods of time, may have pathological consequences, including chronic inflammation or the development of cancer. For the therapeutic use of CAP in wound healing, the role of RONS in resolving inflammation is especially intriguing [48]. Several studies have analyzed molecular changes induced by CAP treatment [58]. Transcriptome analyses of RNA from human cells treated in vitro with CAP, for example, revealed that genes associated with cellular stress response had been elevated after CAP treatment, and increased levels of anti-oxidative enzymes have been observed [59]. A further study also observed a CAP stimulated expression of key genes (IL-6, IL-8, MCP-1, TGF-B1, TGF-132) involved in wound healing cascades, as well as elevated production of collagen type I and alpha-SMA [60]. The same group found CAP induced expression of IL-8, TGF-B1, and TGF-B2, as well as upregulation of antimicrobial peptides of the $B$-defensin family [61]. At the same time, the 2 min CAP applied in this study induced gene expression of key regulators important for inflammation and wound healing, while not causing proliferation, migration, or cell death in keratinocytes. Using in vitro models that mimic various steps of angiogenesis, it has been demonstrated that CAP triggered the generation of nitric oxide [62]. Furthermore, CAP enhanced cell migration and the assembly of endothelial cells into vessel-like structures-hallmarks of the proliferation phase of wound healing [62]. In the same study, CAP treatment of a mouse model with third-degree burn wounds was associated with enhanced angiogenesis, accelerated wound healing, and increased cellular proliferation. The enzyme that catalyzes nitric oxide synthesis, endothelial NO synthase (eNOS), as well as expression of pro-angiogenic markers, PDGFR $\beta$ and CD31, were significantly increased in mouse wounds after CAP. In vitro CAP stimulated pro-angiogenic VEGFA/VEGFR2 signaling [62]. Hence, this study demonstrates the ability of CAP to modulate endothelial nitric oxide synthase signaling and enhances neovascularization in burn wounds. The ability of CAP to induce wound angiogenesis by activating angiogenesis-related molecules has also been shown in keratinocytes, fibroblasts, and endothelial cells [63]. In keratinocytes, significantly increased expression of Artemin, EGF, EG-VEGF, Endothelin-1, FGF-2, IL-8 (CXCL8), and urokinase-type plasminogen activator (uPA) was observed. In fibroblasts, Angiogenin, Endostatin (Col18A1), MCP-1 (CCL2), MMP-9, TIMP-1, uPA, and VEGF had been increased after CAP treatment, and in endothelial cells, the expression of Angiopoietin-2, Angiostatin, Amphiregulin, Endostatin, FGF-2, FGFR1, and VEGFR1 had been activated. By transferring the conditioned medium from CAP-treated fibroblasts and keratinocytes to endothelial cells, the authors demonstrated that CAP modulates pro-angiogenic factors via autocrine and paracrine mechanisms. CAP induced wound angiogenesis was confirmed in vivo by an immunohistochemistry assay assessing the platelet and endothelial cell adhesion molecule CD31 in CAP-treated and placebo-treated tissues. Increased mRNA levels of CD31 and FGF-2 have also been observed in the CAP treated tissue [63]. Positive effects of CAP on angiogenesis by the release of FGF-2 or by the generation of nitric oxide have also been observed by others $[64,65]$. The effects of CAP on paracrine cross-talk between dermal keratinocytes and fibroblasts have also been investigated in a recent study using an in vitro co-culture model. This study identified YAP and its targets CTGF and Cyr61 as drivers for paracrine signaling and CAP mediated wound healing [66]. The authors conclude that the secretion of CTGF and Cyr61 from fibroblasts influences the activation of keratinocytes through paracrine signaling and hence improves cell migration upon wound onset. Intriguingly, 
plasma treatment promotes the antioxidant phase II response elements in keratinocytes, which varies to a certain degree upon changes in the feed gas composition and subsequent RONS chemistry $[67,68]$. Interestingly, the frequent exposure of the same human keratinocyte culture in vitro to plasma pointed to several adaptation processes in these cells, e.g., in antioxidant defense [69]. Enhanced migration of fibroblasts and keratinocytes after CAP treatment has also been observed in vitro in scratch assays [70]. This was correlated with the downregulation of the gap junctional protein connexin 43 , as well as the downregulation of E-cadherin and several integrins. In the same study, the authors report significantly accelerated wound re-epithelialization after CAP treatment of a murine model of dermal full-thickness ear wounds [70]. A decrease of E-cadherin on the protein level after treatment of keratinocytes with CAP conditioned medium was also observed in another recent study [71]. This decrease was accompanied by an increase in N-cadherin, cyclin D1, Ki-67, Cdk2, and p-ERK levels, and together this is evidence for CAP-induced epithelial-mesenchymal transition (EMT) and cell cycle progression supporting proliferation and migration. Collectively, CAP improves wound healing by modulating inflammation, proliferation, angiogenesis/revascularization, migration, and re-epithelialization using pre-existing signaling pathway partially explored in redox biology studies already.

Processes, such as proliferation, angiogenesis, or migration, are important for wound healing, but unwanted with respect to cancer. Therefore, CAP intensities have to be significantly increased for cancer therapy compared to wound treatment to inhibit growth and induce cell death. Higher intensities of CAP lead to higher concentrations of RONS, and supraphysiological levels of oxidative stress disrupt redox signaling and/or cause damage to biomolecules, such as membrane lipids, proteins, and DNA [72]. Such a supraphysiological level of oxidative stress is termed oxidative distress instead of physiological low-level oxidative stress, termed oxidative eustress [73]. While oxidative eustress, as described above, triggers signaling pathways enhancing cell proliferation and tissue regeneration, oxidative distress triggers cell cycle arrest and cell death. The adaptive response to oxidative stress is regulated by modulating the nuclear E2-related factor (Nrf2) pathway, which maintains redox homeostasis and defends cells from damage [45]. In response to increased ROS levels, Nrf2 translocates from the cytosol to the nucleus where it binds to antioxidant responsive elements on DNA and thus promotes the upregulation of antioxidant genes [74]. These genes encode, for example, for glutathione (GSH), glutathione reductase (GSR), glutathione S-transferase (GST), superoxide dismutase (SOD), heme oxygenase 1 (HMOX-1), and NADPH quinine oxidoreductase 1 (NQO1) [45]. Nrf2 signaling has also been identified as a critical event in CAP-induced wound healing [75].

While temporarily increased oxidative stress is beneficial in wound healing, chronically increased supraphysiological levels of RONS are also supporting carcinogenesis and tumor progression [76]. Although cancer cells adapt to the elevated levels of RONS, they also depend on increased activity of the antioxidant system to keep redox homeostasis. It is hypothesized that the increased cellular levels of RONS in cancer cells render them especially sensitive to further exposure to RONS in comparison to their non-malignant counterparts [48,77], although contrary evidence exists as well [78]. Besides plasma treatment time and intensity, the extent of the response to CAP also depends on genetic background, cell type, tumor microenvironment, as well as the different classes of RONS generated [33,79]. Prolonged CAP treatment mediates apoptosis or necrosis, but the induction of cellular senescence and autophagy have also been reported. It is hypothesized that the parameters of treatment time and probably also the type of plasma device govern the biological outcome [80,81]. While senescence, a well-known irreversible growth arrest in response to oxidative stress and DNA damage [82], may be induced by relatively short treatments (regarding the treatment setting used in this study) with CAP, apoptosis, and necrosis are induced by prolonged treatment times. The dose-dependent induction of senescence depends on the cytosolic influx of calcium $[83,84]$. Cell death induced by RONS involves several apoptosis-related signaling pathways, such as MAPK and ERK pathways [85]. RONS play an important role in initiating CAP induced apoptosis by directly oxidizing cellular proteins, lipids, or nucleic acids and causing general damage and dysfunction. Death receptors, such as tumor necrosis factor (TNF) receptor-I, enhance the generation of RONS via the mitochondria, leading to the activation 
of caspases and cell death. However, TNF-induced oxidative stress also activates anti-apoptotic signaling by increasing the expression levels of MnSOD and catalase by nuclear factor- $\mathrm{KB}$ (NF- $\mathrm{KB}$ ) [86]. $\mathrm{NF}-\mathrm{kB}$, in turn, activates the transcription of various genes, such as the uPA and different matrix metalloproteinases [87-89]. These proteases increase motility of different cell types, such as endothelial cells $[90,91]$ and mesenchymal stem/stromal cells $[92,93]$, which is necessary for the reorganization processes in both wound healing and tumor development $[94,95]$.

Taken together, these examples demonstrate that CAP generated RONS may trigger a variety of mechanisms leading to growth arrest or cell death via apoptosis or necrosis. Besides typically elevated levels of RONS in cancer, there are further common differences between cancer cells and their non-malignant counterparts that render these cells more vulnerable to extrinsic oxidative stress than normal cells. While minimal amounts of RONS may diffuse through the cell membrane, it has been suggested that the transition of reactive species into the cytosol is facilitated by aquaporins, which are often increased in membranes of cancer cells [96]. Diffusion of RONS into the cell may also be facilitated by lipid peroxidation caused by reactive species, which then leads to pore formation in the membrane. This effect may be enhanced in cancer cells, due to lower levels of cholesterol in cancer cells [97]. Cholesterol is a lipid important for providing membrane stability and fluidity. These distinct properties of many cancer cells render them especially sensitive and may promote the selective killing of cancer cells through CAP treatment. Lipid peroxidation was, however, only a minor contributor in a recent study that investigated plasma-induced cell death mechanisms [98].

The fact that CAP may enhance proliferation and angiogenesis in wound healing, sparks the question if $\mathrm{CAP}$ used for cancer treatment may pose a risk for carcinogenesis and have tumor-promoting effects. In studies assessing treatment modalities used for wound healing, no apparent side effects, including mutagenicity, tumor formation, or chronic inflammation even one year after CAP treatment, have been observed in mice and humans $[14,99,100]$. Nonetheless, it is a concern that with increased treatment times or intensities for cancer treatment also cancer-promoting effects may be achieved. Therefore, the concern of carcinogenesis or tumor-promoting side effects needs to be addressed in future studies and is already being addressed by existing consortia assessing CAP as a potential cancer therapy in vitro and in vivo.

In summary, research elucidating the molecular mechanisms for the efficacy of CAP in wound healing, and cancer treatment revealed that RONS plays a major role in both applications. Treatment duration and intensities determine the concentration of RONS and hence its effect on treated cells regarding stimulation or inhibition of growth.

\section{Conclusions}

Cold atmospheric pressure plasma (CAP) is a promising innovation for a variety of different applications in medicine. The application of CAP for disinfection, wound healing, and cancer treatment are probably the most investigated areas of application. While clinical evidence is available for wound healing, preclinical studies dominate the novel field of plasma oncology. Efforts to elucidate the mode of action of CAP suggest that different components, such as UV radiation, electromagnetic fields, and reactive species may act synergistically, with the reactive species being regarded as the main effectors acting by targeting redox signaling pathways. While CAP induced oxidative eustress triggers pathways that promote proliferation, angiogenesis, migration, and re-epithelialization and hence, improves wound healing, oxidative distress triggers pathways inducing senescence, apoptosis, or necrosis, as well as an immune response and therefore may be beneficial for cancer treatment. Although much progress has been made in identifying the underlying molecular mechanisms, more research is necessary to fully understand the complex signaling processes involved in the biological responses to CAP treatment.

Author Contributions: Conceptualization, L.B.; methodology, L.B.; resources, S.E.; writing-original draft preparation, L.B.; writing-review and editing, S.B., T.B., S.E., T.F., B.M.-H., O.J., C.S., B.N., G.O., K.P., M.S., M.L.S.; visualization, L.B.; funding acquisition, S.E. All authors have read and agreed to the published version of the manuscript. 
Funding: The joint research project "ONKOTHER-H" is supported by the European Social Fund (ESF), reference: ESF/14-BM-A55-0001/18, 02/18, 05/18 \& 06/18 and the Ministry of Education, Science and Culture of Mecklenburg-West Pomerania, Germany. S.E. is supported by the Damp Stiftung. S.B. is supported by the German Federal Ministry of Education and Research (BMBF), grant numbers 03Z22DN11, 03Z22Di1, and 03Z22D511. Furthermore this work was supported by DFG EM 63/13-1 (S.E.), the TBI project "AmbuPlas" (S.E.) and the FORUN program to promote young scientists at the University Medical Center Rostock (L.B.).

Conflicts of Interest: The authors declare no conflict of interest.

\section{References}

1. Von Woedtke, T.; Reuter, S.; Masur, K.; Weltmann, K.-D. Plasmas for medicine. Phys. Rep. 2013, 530, $291-320$. [CrossRef]

2. Fridman, G.; Friedman, G.; Gutsol, A.; Shekhter, A.B.; Vasilets, V.N.; Fridman, A. Applied Plasma Medicine. Plasma Process. Polym. 2008, 5, 503-533. [CrossRef]

3. Metelmann, H.-R.; Woedtke, T.; Weltmann, K.-D. Comprehensive Clinical Plasma Medicine: Cold Physical Plasma for Medical Application; Springer International Publishing: Midtown Manhattan, NY, USA, 2018.

4. Bernhardt, T.; Semmler, M.L.; Schäfer, M.; Bekeschus, S.; Emmert, S.; Boeckmann, L. Plasma Medicine: Applications of Cold Atmospheric Pressure Plasma in Dermatology. Oxid. Med. Cell. Longev. 2019, 2019, 1-10. [CrossRef] [PubMed]

5. Boeckmann, L.; Bernhardt, T.; Schäfer, M.; Semmler, M.L.; Kordt, M.; Waldner, A.; Wendt, F.; Sagwal, S.; Bekeschus, S.; Berner, J.; et al. Aktuelle Indikationen der Plasmatherapie in der Dermatologie. Der Hautarzt 2020, 71, 109-113. [CrossRef] [PubMed]

6. Isbary, G.; Morfill, G.; Schmidt, H.; Georgi, M.; Ramrath, K.; Heinlin, J.; Karrer, S.; Landthaler, M.; Shimizu, T.; Steffes, B.; et al. A first prospective randomized controlled trial to decrease bacterial load using cold atmospheric argon plasma on chronic wounds in patients. Br. J. Dermatol. 2010, 163, 78-82. [CrossRef] [PubMed]

7. Isbary, G.; Heinlin, J.; Shimizu, T.; Zimmermann, J.; Morfill, G.; Schmidt, H.-U.; Monetti, R.; Steffes, B.; Bunk, W.; Li, Y.; et al. Successful and safe use of 2 min cold atmospheric argon plasma in chronic wounds: Results of a randomized controlled trial. Br. J. Dermatol. 2012, 167, 404-410. [CrossRef]

8. Klebes, M.; Ulrich, C.; Kluschke, F.; Patzelt, A.; Vandersee, S.; Richter, H.; Bob, A.; Von Hutten, J.; Krediet, J.T.; Kramer, A.; et al. Combined antibacterial effects of tissue-tolerable plasma and a modern conventional liquid antiseptic on chronic wound treatment. J. Biophotonics 2015, 8, 382-391. [CrossRef]

9. Ulrich, C.; Kluschke, F.; Patzelt, A.; Vandersee, S.; Czaika, M.V.A.; Richter, H.; Bob, A.; Von Hutten, J.; Painsi, C.; Huge, R.; et al. Clinical use of cold atmospheric pressure argon plasma in chronic leg ulcers: A pilot study. J. Wound Care 2015, 24, 196-203. [CrossRef]

10. Isbary, G.; Stolz, W.; Shimizu, T.; Monetti, R.; Bunk, W.; Schmidt, H.-U.; Morfill, G.E.; Klämpfl, T.G.; Steffes, B.; Thomas, H.M.; et al. Cold atmospheric argon plasma treatment may accelerate wound healing in chronic wounds: Results of an open retrospective randomized controlled study in vivo. Clin. Plasma Med. 2013, 1, 25-30. [CrossRef]

11. Brehmer, F.; Haenssle, H.A.; Daeschlein, G.; Ahmed, R.; Pfeiffer, S.; Görlitz, A.; Simon, D.; Schon, M.P.; Wandke, D.; Emmert, S. Alleviation of chronic venous leg ulcers with a hand-held dielectric barrier discharge plasma generator (PlasmaDerm((R))VU-2010): Results of a monocentric, two-armed, open, prospective, randomized and controlled trial (NCT01415622). J. Eur. Acad. Dermatol. Venereol. 2015, 29, 148-155. [CrossRef]

12. Chuangsuwanich, A.; Assadamongkol, T.; Boonyawan, D. The Healing Effect of Low-Temperature Atmospheric-Pressure Plasma in Pressure Ulcer. Int. J. Low. Extremity Wounds 2016, 15, 313-319. [CrossRef] [PubMed]

13. Metelmann, H.-R.; Woedtke, T.; Bussiahn, R.; Weltmann, K.-D.; Rieck, M.; Khalili, R.; Podmelle, F.; Waite, P.D. Experimental Recovery of CO2-Laser Skin Lesions by Plasma Stimulation. Am. J. Cosmet. Surg. 2012, 29, 52-56. [CrossRef]

14. Metelmann, H.-R.; Vu, T.T.; Do, H.T.; Le, T.N.B.; Hoang, T.H.A.; Phi, T.T.T.; Luong, T.M.L.; Van Doan, V.T.; Nguyen, T.T.H.; Nguyen, T.H.M.; et al. Scar formation of laser skin lesions after cold atmospheric pressure plasma (CAP) treatment: A clinical long term observation. Clin. Plasma Med. 2013, 1, 30-35. [CrossRef] 
15. Vandersee, S.; Richter, H.; Lademann, J.; Beyer, M.; Kramer, A.; Knorr, F.; Lange-Asschenfeldt, B. Laser scanning microscopy as a means to assess the augmentation of tissue repair by exposition of wounds to tissue tolerable plasma. Laser Phys. Lett. 2014, 11, 115701. [CrossRef]

16. Heinlin, J.; Zimmermann, J.L.; Zeman, F.; Bunk, W.; Isbary, G.; Landthaler, M.; Maisch, T.; Monetti, R.; Morfill, G.; Shimizu, T.; et al. Randomized placebo-controlled human pilot study of cold atmospheric argon plasma on skin graft donor sites. Wound Repair Regen. 2013, 21, 800-807. [CrossRef]

17. Assadian, O.; Ousey, K.J.; Daeschlein, G.; Kramer, A.; Parker, C.; Tanner, J.; Leaper, D.J. Effects and safety of atmospheric low-temperature plasma on bacterial reduction in chronic wounds and wound size reduction: A systematic review and meta-analysis. Int. Wound J. 2018, 16, 103-111. [CrossRef]

18. Stratmann, B.; Costea, T.-C.; Nolte, C.; Hiller, J.; Schmidt, J.; Reindel, J.; Masur, K.; Motz, W.; Timm, J.; Kerner, W.; et al. Effect of Cold Atmospheric Plasma Therapy vs Standard Therapy Placebo on Wound Healing in Patients With Diabetic Foot Ulcers. JAMA Netw. Open 2020, 3, e2010411. [CrossRef]

19. Mirpour, S.; Fathollah, S.; Mansouri, P.; Larijani, B.; Ghoranneviss, M.; Tehrani, M.M.; Amini, M.R. Cold atmospheric plasma as an effective method to treat diabetic foot ulcers: A randomized clinical trial. Sci. Rep. 2020, 10, 1-9. [CrossRef]

20. Hoffmann, M.; Bruch, H.-P.; Kujath, P.; Limmer, S. Cold-plasma coagulation in the treatment of malignant pleural mesothelioma: Results of a combined approach. Interact. Cardiovasc. Thorac. Surg. 2010, 10, 502-505. [CrossRef]

21. Metelmann, H.-R.; Nedrelow, D.S.; Seebauer, C.; Schuster, M.; Von Woedtke, T.; Weltmann, K.-D.; Kindler, S.; Metelmann, P.H.; Finkelstein, S.E.; Von Hoff, D.D.; et al. Head and neck cancer treatment and physical plasma. Clin. Plasma Med. 2015, 3, 17-23. [CrossRef]

22. Schuster, M.; Seebauer, C.; Rutkowski, R.; Hauschild, A.; Podmelle, F.; Metelmann, C.; Metelmann, B.; Von Woedtke, T.; Hasse, S.; Weltmann, K.-D.; et al. Visible tumor surface response to physical plasma and apoptotic cell kill in head and neck cancer. J. Cranio-Maxillofac. Surg. 2016, 44, 1445-1452. [CrossRef] [PubMed]

23. Friedman, P.C.; Miller, V.; Fridman, G.; Lin, A.; Fridman, A. Successful treatment of actinic keratoses using nonthermal atmospheric pressure plasma: A case series. J. Am. Acad. Dermatol. 2017, 76, 349-350. [CrossRef] [PubMed]

24. Metelmann, H.-R.; Seebauer, C.; Miller, V.; Fridman, A.; Bauer, G.; Graves, D.B.; Pouvesle, J.-M.; Rutkowski, R.; Schuster, M.; Bekeschus, S.; et al. Clinical experience with cold plasma in the treatment of locally advanced head and neck cancer. Clin. Plasma Med. 2018, 9, 6-13. [CrossRef]

25. Wirtz, M.; Stoffels, I.; Dissemond, J.; Schadendorf, D.; Roesch, A. Actinic keratoses treated with cold atmospheric plasma. J. Eur. Acad. Dermatol. Venereol. 2017, 32, 37. [CrossRef]

26. Privat-Maldonado, A.; Bengtson, C.; Razzokov, J.; Smits, E.; Bogaerts, A. Modifying the Tumour Microenvironment: Challenges and Future Perspectives for Anticancer Plasma Treatments. Cancers 2019, 11, 1920. [CrossRef]

27. Dubuc, A.; Monsarrat, P.; Virard, F.; Merbahi, N.; Sarrette, J.-P.; Laurencin-Dalicieux, S.; Cousty, S. Use of cold-atmospheric plasma in oncology: A concise systematic review. Ther. Adv. Med Oncol. 2018, 10, 1758835918786475. [CrossRef]

28. Calugaru, A.; Cremer, L.; Herold, A.; Lupu, A.; Szegli, G.; Lungu, C.; Lungu, A.; Georgescu, N. The effect of the plasma needle on tumoral cell lines apoptosis. Roum. Arch. Microbiol. Immunol. 2007, 64, 57.

29. Chernets, N.; Kurpad, D.S.; Alexeev, V.; Rodrigues, D.B.; Freeman, T.A. Reaction Chemistry Generated by Nanosecond Pulsed Dielectric Barrier Discharge Treatment is Responsible for the Tumor Eradication in the B16 Melanoma Mouse Model. Plasma Process. Polym. 2015, 12, 1400-1409. [CrossRef]

30. Keidar, M.; Walk, R.; Shashurin, A.; Srinivasan, P.; Sandler, A.; Dasgupta, S.; Ravi, R.; Guerrero-Preston, R.E.; Trink, B. Cold plasma selectivity and the possibility of a paradigm shift in cancer therapy. Br. J. Cancer 2011, 105, 1295-1301. [CrossRef]

31. Bekeschus, S.; Clemen, R.; Nießner, F.; Sagwal, S.K.; Freund, E.; Schmidt, A. Medical Gas Plasma Jet Technology Targets Murine Melanoma in an Immunogenic Fashion. Adv. Sci. 2020, 7, 1903438. [CrossRef]

32. Brullé, L.; Vandamme, M.; Riès, D.; Martel, É.; Robert, É.; Lerondel, S.; Trichet, V.; Richard, S.; Pouvesle, J.-M.; Le Pape, A. Effects of a Non Thermal Plasma Treatment Alone or in Combination with Gemcitabine in a MIA PaCa2-luc Orthotopic Pancreatic Carcinoma Model. PLoS ONE 2012, 7, e52653. [CrossRef] [PubMed] 
33. Semmler, M.L.; Bekeschus, S.; Schäfer, M.; Bernhardt, T.; Fischer, T.; Witzke, K.; Seebauer, C.; Rebl, H.; Grambow, E.; Vollmar, B.; et al. Molecular Mechanisms of the Efficacy of Cold Atmospheric Pressure Plasma (CAP) in Cancer Treatment. Cancers 2020, 12, 269. [CrossRef] [PubMed]

34. Lademann, J.; Richter, H.; Alborova, A.; Humme, D.; Patzelt, A.; Kramer, A.; Weltmann, K.-D.; Hartmann, B.; Ottomann, C.; Fluhr, J.W.; et al. Risk assessment of the application of a plasma jet in dermatology. J. Biomed. Opt. 2009, 14, 054025. [CrossRef] [PubMed]

35. Heinlin, J.; Isbary, G.; Stolz, W.; Morfill, G.; Landthaler, M.; Shimizu, T.; Steffes, B.; Nosenko, T.; Zimmermann, J.; Karrer, S. Plasma applications in medicine with a special focus on dermatology. J. Eur. Acad. Dermatol. Venereol. 2010, 25, 1-11. [CrossRef] [PubMed]

36. Bekeschus, S.; Schmidt, A.; Weltmann, K.-D.; Von Woedtke, T. The plasma jet kINPen - A powerful tool for wound healing. Clin. Plasma Med. 2016, 4, 19-28. [CrossRef]

37. Recio, A.C.; Felter, C.E.; Schneider, A.C.; McDonald, J.W. High-voltage electrical stimulation for the management of Stage III and IV pressure ulcers among adults with spinal cord injury: Demonstration of its utility for recalcitrant wounds below the level of injury. J. Spinal Cord Med. 2012, 35, 58-63. [CrossRef]

38. Houghton, P.E.; Campbell, K.E.; Fraser, C.H.; Harris, C.; Keast, D.H.; Potter, P.J.; Hayes, K.C.; Woodbury, M.G. Electrical Stimulation Therapy Increases Rate of Healing of Pressure Ulcers in Community-Dwelling People With Spinal Cord Injury. Arch. Phys. Med. Rehabil. 2010, 91, 669-678. [CrossRef]

39. Gardner, S.E.; Frantz, R.A.; Schmidt, F.L. Effect of electrical stimulation on chronic wound healing: A meta-analysis. Wound Repair Regen. 1999, 7, 495-503. [CrossRef]

40. Cho, M.R.; Thatte, H.S.; Lee, R.C.; Golan, D.E. Integrin-dependent human macrophage migration induced by oscillatory electrical stimulation. Ann. Biomed. Eng. 2000, 28, 234-243. [CrossRef]

41. Goldman, R.; Pollack, S. Electric fields and proliferation in a chronic wound model. Bioelectromagnetics 1996, 17, 450-457. [CrossRef]

42. Pullar, C.E.; Baier, B.S.; Kariya, Y.; Russell, A.J.; Horst, B.A.; Marinkovich, M.P.; Isseroff, R.R. $\beta 4$ Integrin and Epidermal Growth Factor Coordinately Regulate Electric Field-mediated Directional Migration via Rac1. Mol. Boil. Cell 2006, 17, 4925-4935. [CrossRef] [PubMed]

43. Daeschlein, G.; Assadian, O.; Kloth, L.C.; Meinl, C.; Ney, F.; Kramer, A. Antibacterial activity of positive and negative polarity low-voltage pulsed current (LVPC) on six typical Gram-positive and Gram-negative bacterial pathogens of chronic wounds. Wound Repair Regen. 2007, 15, 399-403. [CrossRef] [PubMed]

44. Wolff, C.M.; Steuer, A.; Stoffels, I.; Von Woedtke, T.; Weltmann, K.-D.; Bekeschus, S.; Kolb, J.F. Combination of cold plasma and pulsed electric fields - A rationale for cancer patients in palliative care. Clin. Plasma Med. 2019, 16, 100096. [CrossRef]

45. Von Woedtke, T.; Schmidt, A.; Bekeschus, S.; Wende, K.; Weltmann, K.-D. Plasma Medicine: A Field of Applied Redox Biology. In Vivo 2019, 33, 1011-1026. [CrossRef]

46. Roy, J.; Galano, J.-M.; Durand, T.; Le Guennec, J.-Y.; Lee, J.C.-Y. Physiological role of reactive oxygen species as promoters of natural defenses. FASEB J. 2017, 31, 3729-3745. [CrossRef] [PubMed]

47. Dröge, W. Free Radicals in the Physiological Control of Cell Function. Physiol. Rev. 2002, 82, 47-95. [CrossRef]

48. Graves, D.B. The emerging role of reactive oxygen and nitrogen species in redox biology and some implications for plasma applications to medicine and biology. J. Phys. D Appl. Phys. 2012, 45, 263001. [CrossRef]

49. Broughton, G.; Janis, J.E.; Attinger, C.E. The Basic Science of Wound Healing. Plast. Reconstr. Surg. 2006, 117, 12S-34S. [CrossRef]

50. Pastar, I.; Stojadinovic, O.; Yin, N.C.; Ramírez, H.; Nusbaum, A.G.; Sawaya, A.; Patel, S.B.; Khalid, L.; Isseroff, R.R.; Tomic-Canic, M. Epithelialization in Wound Healing: A Comprehensive Review. Adv. Wound Care 2014, 3, 445-464. [CrossRef]

51. Soneja, A.; Drews, M.; Malinski, T. Role of nitric oxide, nitroxidative and oxidative stress in wound healing. Pharmacol. Rep. 2005, 57, 108-119.

52. Nathan, C.; Ding, A. Nonresolving Inflammation. Cell 2010, 140, 871-882. [CrossRef] [PubMed]

53. Thomas, D.D.; Ridnour, L.A.; Isenberg, J.S.; Flores-Santana, W.; Switzer, C.H.; Donzelli, S.; Hussain, P.; Vecoli, C.; Paolocci, N.; Ambs, S.; et al. The chemical biology of nitric oxide: Implications in cellular signaling. Free. Radic. Biol. Med. 2008, 45, 18-31. [CrossRef] [PubMed]

54. Sen, C.K.; Roy, S. Redox signals in wound healing. Biochim. et Biophys. Acta Gen. Subj. 2008, 1780, $1348-1361$. [CrossRef] [PubMed]

55. Witte, M.B.; Barbul, A. Role of nitric oxide in wound repair. Am. J. Surg. 2002, 183, 406-412. [CrossRef] 
56. Luo, J.-D.; Chen, A.F. Nitric oxide: A newly discovered function on wound healing. Acta Pharmacol. Sin. 2005, 26, 259-264. [CrossRef]

57. Roy, S.; Khanna, S.; Nallu, K.; Hunt, T.K.; Sen, C.K. Dermal Wound Healing Is Subject to Redox Control. Mol. Ther. 2006, 13, 211-220. [CrossRef]

58. Schmidt, A.; Bekeschus, S. Redox for Repair: Cold Physical Plasmas and Nrf2 Signaling Promoting Wound Healing. Antioxidants 2018, 7, 146. [CrossRef]

59. Schmidt, A.; Wende, K.; Bekeschus, S.; Bundscherer, L.; Barton, A.; Ottmüller, K.; Weltmann, K.-D.; Masur, K. Non-thermal plasma treatment is associated with changes in transcriptome of human epithelial skin cells. Free. Radic. Res. 2013, 47, 577-592. [CrossRef]

60. Arndt, S.; Unger, P.; Wacker, E.; Shimizu, T.; Heinlin, J.; Li, Y.-F.; Thomas, H.M.; Morfill, G.E.; Zimmermann, J.L.; Bosserhoff, A.-K.; et al. Cold Atmospheric Plasma (CAP) Changes Gene Expression of Key Molecules of the Wound Healing Machinery and Improves Wound Healing In Vitro and In Vivo. PLoS ONE 2013, 8, e79325. [CrossRef]

61. Arndt, S.; Landthaler, M.; Zimmermann, J.L.; Unger, P.; Wacker, E.; Shimizu, T.; Li, Y.-F.; Morfill, G.E.; Bosserhoff, A.-K.; Karrer, S. Effects of Cold Atmospheric Plasma (CAP) on B-Defensins, Inflammatory Cytokines, and Apoptosis-Related Molecules in Keratinocytes In Vitro and In Vivo. PLoS ONE 2015, 10, e0120041. [CrossRef]

62. Duchesne, C.; Banzet, S.; Lataillade, J.; Rousseau, A.; Frescaline, N. Cold atmospheric plasma modulates endothelial nitric oxide synthase signalling and enhances burn wound neovascularisation. J. Pathol. 2019, 249, 368-380. [CrossRef] [PubMed]

63. Arndt, S.; Unger, P.; Berneburg, M.; Bosserhoff, A.-K.; Karrer, S. Cold atmospheric plasma (CAP) activates angiogenesis-related molecules in skin keratinocytes, fibroblasts and endothelial cells and improves wound angiogenesis in an autocrine and paracrine mode. J. Dermatol. Sci. 2018, 89, 181-190. [CrossRef] [PubMed]

64. Arjunan, K.P.; Clyne, A.M. A Nitric Oxide Producing Pin-to-Hole Spark Discharge Plasma Enhances Endothelial Cell Proliferation and Migration. Plasma Med. 2011, 1, 279-293. [CrossRef]

65. Kalghatgi, S.; Friedman, G.; Fridman, A.; Clyne, A.M. Endothelial Cell Proliferation is Enhanced by Low Dose Non-Thermal Plasma Through Fibroblast Growth Factor-2 Release. Ann. Biomed. Eng. 2009, 38, 748-757. [CrossRef] [PubMed]

66. Shome, D.; Von Woedtke, T.; Riedel, K.; Masur, K. The HIPPO Transducer YAP and Its Targets CTGF and Cyr61 Drive a Paracrine Signalling in Cold Atmospheric Plasma-Mediated Wound Healing. Oxidative Med. Cell. Longev. 2020, 2020, 4910280. [CrossRef]

67. Schmidt, A.; Dietrich, S.; Steuer, A.; Weltmann, K.-D.; Von Woedtke, T.; Masur, K.; Wende, K. Non-thermal Plasma Activates Human Keratinocytes by Stimulation of Antioxidant and Phase II Pathways. J. Boil. Chem. 2015, 290, 6731-6750. [CrossRef] [PubMed]

68. Schmidt, A.; Bekeschus, S.; Jablonowski, H.; Barton, A.; Weltmann, K.-D.; Wende, K. Role of Ambient Gas Composition on Cold Physical Plasma-Elicited Cell Signaling in Keratinocytes. Biophys. J. 2017, 112, 2397-2407. [CrossRef]

69. Schmidt, A.; Von Woedtke, T.; Bekeschus, S. Periodic Exposure of Keratinocytes to Cold Physical Plasma: An In Vitro Model for Redox-Related Diseases of the Skin. Oxidative Med. Cell. Longev. 2016, 2016, 1-17. [CrossRef]

70. Schmidt, A.; Bekeschus, S.; Wende, K.; Vollmar, B.; Von Woedtke, T. A cold plasma jet accelerates wound healing in a murine model of full-thickness skin wounds. Exp. Dermatol. 2017, 26, 156-162. [CrossRef]

71. Lou, B.-S.; Hsieh, J.-H.; Chen, C.-M.; Hou, C.-W.; Wu, H.-Y.; Chou, P.-Y.; Lai, C.-H.; Lee, J.-W. Helium/Argon-Generated Cold Atmospheric Plasma Facilitates Cutaneous Wound Healing. Front. Bioeng. Biotechnol. 2020, 8, 683. [CrossRef]

72. Bekeschus, S.; Schmidt, A.; Niessner, F.; Gerling, T.; Weltmann, K.-D.; Wende, K. Basic Research in Plasma Medicine-A Throughput Approach from Liquids to Cells. J. Vis. Exp. 2017, e56331. [CrossRef] [PubMed]

73. Sies, H. On the history of oxidative stress: Concept and some aspects of current development. Curr. Opin. Toxicol. 2018, 7, 122-126. [CrossRef]

74. Holmstrom, K.; Finkel, T. Cellular mechanisms and physiological consequences of redox-dependent signalling. Nat. Rev. Mol. Cell Boil. 2014, 15, 411-421. [CrossRef] [PubMed]

75. Schmidt, A.; Von Woedtke, T.; Vollmar, B.; Hasse, S.; Bekeschus, S. Nrf2 signaling and inflammation are key events in physical plasma-spurred wound healing. Theranostics 2019, 9, 1066-1084. [CrossRef] 
76. Pan, J.-S.; Hong, M.-Z.; Ren, J.-L. Reactive oxygen species: A double-edged sword in oncogenesis. World J. Gastroenterol. 2009, 15, 1702-1707. [CrossRef]

77. Glasauer, A.; Chandel, N.S. Targeting antioxidants for cancer therapy. Biochem. Pharmacol. 2014, 92, 90-101. [CrossRef]

78. Hole, P.S.; Zabkiewicz, J.; Munje, C.; Newton, Z.; Pearn, L.; White, P.; Marquez, N.; Hills, R.; Burnett, A.K.; Tonks, A.; et al. Overproduction of NOX-derived ROS in AML promotes proliferation and is associated with defective oxidative stress signaling. Blood 2013, 122, 3322-3330. [CrossRef]

79. Kong, Q.; Beel, J.; Lillehei, K. A threshold concept for cancer therapy. Med. Hypotheses 2000, 55, $29-35$. [CrossRef]

80. Fridman, G.; Shereshevsky, A.; Jost, M.M.; Brooks, A.D.; Fridman, A.; Gutsol, A.; Vasilets, V.N.; Friedman, G. Floating Electrode Dielectric Barrier Discharge Plasma in Air Promoting Apoptotic Behavior in Melanoma Skin Cancer Cell Lines. Plasma Chem. Plasma Process. 2007, 27, 163-176. [CrossRef]

81. Lupu, A.-R.; Georgescu, N. Cold atmospheric plasma jet effects on V79-4 cells. Roum. Arch. Microbiol. Immunol. 2011, 69, 67-74.

82. Regulski, M.J. Cellular Senescence: What, Why, and How. Wounds 2017, 29, 168-174. [PubMed]

83. Arndt, S.; Wacker, E.; Li, Y.-F.; Shimizu, T.; Thomas, H.M.; Morfill, G.E.; Karrer, S.; Zimmermann, J.L.; Bosserhoff, A.-K. Cold atmospheric plasma, a new strategy to induce senescence in melanoma cells. Exp. Dermatol. 2013, 22, 284-289. [CrossRef] [PubMed]

84. Schneider, C.; Gebhardt, L.; Arndt, S.; Karrer, S.; Zimmermann, J.L.; Fischer, M.J.M.; Bosserhoff, A.-K. Cold atmospheric plasma causes a calcium influx in melanoma cells triggering CAP-induced senescence. Sci. Rep. 2018, 8, 10048. [CrossRef] [PubMed]

85. Zhang, J.; Wang, X.; Vikash, V.; Ye, Q.; Wu, D.; Liu, Y.; Dong, W. ROS and ROS-Mediated Cellular Signaling. Oxidative Med. Cell. Longev. 2016, 2016, 1-18. [CrossRef] [PubMed]

86. Mitra, S.; Nguyen, L.N.; Akter, M.; Park, G.; Choi, E.; Choi, E. Impact of ROS Generated by Chemical, Physical, and Plasma Techniques on Cancer Attenuation. Cancers 2019, 11, 1030. [CrossRef]

87. Kolev, K.; Skopál, J.; Simon, L.; Csonka, É.; Nagy, Z.; Machovich, R. Matrix metalloproteinase-9 expression in post-hypoxic human brain capillary endothelial cells: $\mathrm{H}_{2} \mathrm{O}_{2}$ as a trigger and NF- $\mathrm{KB}$ as a signal transducer. Thromb. Haemost. 2003, 90, 528-537. [CrossRef]

88. Tobar, N.; Villar, V.; Santibañez, J.F. ROS-NFkB mediates TGF- $\beta 1$-induced expression of urokinase-type plasminogen activator, matrix metalloproteinase-9 and cell invasion. Mol. Cell. Biochem. 2010, 340, 195-202. [CrossRef]

89. Van Der Heiden, K.; Cuhlmann, S.; Luong, L.A.; Zakkar, M.; Evans, P.C. Role of nuclear factor $\kappa B$ in cardiovascular health and disease. Clin. Sci. 2010, 118, 593-605. [CrossRef]

90. Jansen, P.L.; Rosch, R.; Jansen, M.; Binnebösel, M.; Junge, K.; Alfonso-Jaume, A.; Klinge, U.; Lovett, D.H.; Mertens, P.R. Regulation of MMP-2 Gene Transcription in Dermal Wounds. J. Investig. Dermatol. 2007, 127, 1762-1767. [CrossRef]

91. Montesinos, M.C.; Desai-Merchant, A.; Cronstein, B.N. Promotion of Wound Healing by an Agonist of Adenosine A2A Receptor Is Dependent on Tissue Plasminogen Activator. Inflammation 2015, 38, 2036-2041. [CrossRef]

92. Kim, C.H.; Lee, J.H.; Won, J.-H.; Cho, M.K. Mesenchymal Stem Cells Improve Wound Healing In Vivo via Early Activation of Matrix Metalloproteinase-9 and Vascular Endothelial Growth Factor. J. Korean Med Sci. 2011, 26, 726-733. [CrossRef] [PubMed]

93. Zou, Z.; Zhang, Y.; Hao, L.; Wang, F.; Liu, D.; Su, Y.; Sun, H. More insight into mesenchymal stem cells and their effects inside the body. Expert Opin. Boil. Ther. 2010, 10, 215-230. [CrossRef] [PubMed]

94. Amar, S.; Smith, L.; Fields, G.B. Matrix metalloproteinase collagenolysis in health and disease. Biochim. Biophys. Acta Bioenerg 2017, 1864, 1940-1951. [CrossRef] [PubMed]

95. Dreymüller, D.; Theodorou, K.; Donners, M.M.; Ludwig, A. Fine Tuning Cell Migration by a Disintegrin and Metalloproteinases. Mediat. Inflamm. 2017, 2017, 1-22. [CrossRef]

96. Yan, D.; Xiao, H.; Zhu, W.; Nourmohammadi, N.; Zhang, L.G.; Bian, K.; Keidar, M. The role of aquaporins in the anti-glioblastoma capacity of the cold plasma-stimulated medium. J. Phys. D Appl. Phys. 2017, 50, 055401. [CrossRef] 
97. Van Der Paal, J.; Neyts, E.C.; Verlackt, C.C.W.; Bogaerts, A. Effect of lipid peroxidation on membrane permeability of cancer and normal cells subjected to oxidative stresst +Electronic supplementary information (ESI) available. See doi:10.1039/c5sc02311d Click here for additional data file. Chem. Sci. 2015, 7, 489-498. [CrossRef] [PubMed]

98. Wolff, C.M.; Kolb, J.F.; Weltmann, K.-D.; Von Woedtke, T.; Bekeschus, S. Combination Treatment with Cold Physical Plasma and Pulsed Electric Fields Augments ROS Production and Cytotoxicity in Lymphoma. Cancers 2020, 12, 845. [CrossRef]

99. Schmidt, A.; Von Woedtke, T.; Stenzel, J.; Lindner, T.; Polei, S.; Vollmar, B.; Bekeschus, S. One Year Follow-Up Risk Assessment in SKH-1 Mice and Wounds Treated with an Argon Plasma Jet. Int. J. Mol. Sci. 2017, 18, 868. [CrossRef]

100. Wende, K.; Bekeschus, S.; Schmidt, A.; Jatsch, L.; Hasse, S.; Weltmann, K.; Masur, K.; Von Woedtke, T. Risk assessment of a cold argon plasma jet in respect to its mutagenicity. Mutat. Res. Toxicol. Environ. Mutagen. 2016, 798, 48-54. [CrossRef]

(C) 2020 by the authors. Licensee MDPI, Basel, Switzerland. This article is an open access article distributed under the terms and conditions of the Creative Commons Attribution (CC BY) license (http://creativecommons.org/licenses/by/4.0/). 